\title{
Comparison of analyses to predict ruminal fibre degradability and indigestible fibre in temperate grass silages
}

\author{
F. Jančík ${ }^{\#}$, V. Koukolová, P. Homolka \& J. Haman \\ Institute of Animal Science, Prague Uhř́něves, Přátelství 815, 10400, Czech Republic \\ Copyright resides with the authors in terms of the Creative Commons Attribution 2.5 South African Licence. \\ See: http://creativecommons.org/licenses/by/2.5/za \\ Condition of use: The user may copy, distribute, transmit and adapt the work, but must recognise the authors and the South African Journal \\ of Animal Science.
}

\begin{abstract}
The objective of this study was to compare the ruminal degradability of neutral detergent fibre (NDF) and indigestible NDF (INDF) between silages $(\mathrm{n}=24)$ that originated from three different temperate grass species, i.e. Dactylis glomerata L., Festuca arundinacea L. and hybrid, Felina - Lolium multiflorum L. $\times$ Festuca arundinacea $\mathrm{S}$. The data is used to create prediction equations for the effective degradability of NDF $\left(\mathrm{ED}_{\mathrm{NDF}}\right.$ ), assuming ruminal solid outflow rates of 0.02 (low), 0.05 (medium) and $0.08 / \mathrm{h}$ (high), and INDF. The highest values for the potentially degradable fraction of $\mathrm{NDF}(b), \mathrm{ED}_{\mathrm{NDF} 2}, \mathrm{ED}_{\mathrm{NDF} 5}$ and $\mathrm{ED}_{\mathrm{NDF} 8}(874,560$, 366 and $272 \mathrm{~g} / \mathrm{kg} \mathrm{NDF}$, respectively) and the lowest for INDF (73.1 g/kg DM) were found for $F$. arundinacea. These parameters were significantly different from the hybrid Felina, which presented the lowest rate of NDF degradation (c), $\mathrm{ED}_{\mathrm{NDF} 5}$ and $\mathrm{ED}_{\mathrm{NDF}}(0.033 / \mathrm{h}, 341$ and $250 \mathrm{~g} / \mathrm{kg} \mathrm{NDF}$, respectively). The highest for $c(0.038 / \mathrm{h})$ and INDF $(86.9 \mathrm{~g} / \mathrm{kg} \mathrm{DM})$ and the lowest for $b(847 \mathrm{~g} / \mathrm{kg}$ NDF $)$ were detected for D. glomerata. The combination of acid detergent fibre (ADF) and acid detergent lignin (ADL) $\left(\mathrm{R}^{2}=0.844\right)$ were identified by a backward, stepwise, multiple regression analysis as the most accurate to predict INDF. Crude protein, $\mathrm{ADF}$ and NDF were found as the most suitable combination for predicting $\mathrm{ED}_{\mathrm{NDF} 2}\left(\mathrm{R}^{2}=\right.$ $0.715), \mathrm{ED}_{\mathrm{NDF} 5}\left(\mathrm{R}^{2}=0.669\right)$ and $\mathrm{ED}_{\mathrm{NDF}}\left(\mathrm{R}^{2}=0.648\right)$. Calculated equations found practical application in laboratory analyses to evaluate the nutritional quality of feeds for ruminants.
\end{abstract}

Keywords: Grass silage, neutral detergent fibre, rumen degradation, prediction equations

" Corresponding author: jancik.filip@vuzv.cz

\section{Introduction}

Grass is one of the most important sources of nutrients for domesticated ruminants during a large part of the year (Taweel et al., 2005). Yan \& Agnew (2004) noted that despite being a major feed for ruminants across the world, the nutritive value of grass silage is extremely variable. The digestibility of the different grass species could be distinctly different, and is also influenced by area of origin, including temperature, light intensity, total rainfall, soil type, fertilization level, and by stage of maturity and preservation method (Huhtanen et al., 2006; Jančík et al., 2009). This is especially evident in the rate and extent of ruminal degradation of neutral detergent fibre (NDF) (Hoffman et al., 1993). Several authors have compared the chemical composition and NDF degradability of different grass species (Cherney et al., 1993; Hoffman et al., 1993; Jensen et al., 2003). However, comparisons of NDF degradability and indigestible neutral detergent fibre (INDF) of grass silages, made from Dactylis glomerata, Festuca arundinacea and grass hybrids (Lolium multiflorum L. × Festuca arundinacea S.) grown under the same conditions, are lacking.

The extent and rate of digestion of structural carbohydrates of the cell wall, which is mainly degraded in the rumen with the aid of ruminal microorganisms (Zhang et al., 2007), are highly related to the nutritive value of ruminant feeds (Andrés et al., 2005). The NDF concentration, which represents cell walls of feeds, could be affected by several factors such as temperature, light intensity, water availability, latitude, maturity, and harvesting and storage methods (Van Soest, 1994). Furthermore, the intrinsic characteristics of the carbohydrate fraction, such as the proportion of starch or cellulose and lignification of the cell wall, could 
have an influence on the rate of fermentation of feeds (Nagadi et al., 2000). Indigestible neutral detergent fibre is a part of the cell wall that is unavailable to microbial digestion in ruminants, even when the total tract residence time of the fibre could be extended to an infinite time period (Van Soest, 1994). Lund et al. (2004) showed that the NDF concentration and potential digestibility of NDF are important factors to be included in new feed evaluation systems. If the incorporation of degradation characteristics into a forage quality prediction system seems promising, methods to replace laborious conventional in situ or in vitro procedures to estimate these characteristics on a routine basis, should be evaluated (Hackmann et al., 2008).

The objectives of the present study were to (1) compare ruminal degradability parameters of NDF and indigestible NDF (INDF) among silages made from three different grasses, and (2) to develop prediction equations for ruminal degradability parameters of NDF and INDF from their chemical composition.

\section{Materials and Methods}

Twenty four silage samples made from three different temperate grasses, i.e. orchardgrass - Dactylis glomerata L. cv. Dana; fescue - Festuca arundinacea L. cv. Prolate and the hybrid Felina - Lolium multiflorum L. $\times$ Festuca arundinacea S. cv. Felina were evaluated in the present study. The grass was harvested from the primary growth of monocultured grasses on 19 and 26 May of 2004 and 27 May and 10 June of 2005 at the Větrov Breeding Station, Tábor region, Czech Republic (49 $31^{\prime} 2.04^{\prime \prime}$ N lat, 14 $28^{\prime} 49^{\prime \prime}$ E long; $620 \mathrm{~m}$ altitude). The growth stages of the grass used for silage making are presented in Table 1 . The annual mean temperatures in 2004 and 2005 were 8.4 and $8.3^{\circ} \mathrm{C}$, and the annual rainfall 1020 and $1047 \mathrm{~mm}$, respectively. The grass was wilted for up to $4 \mathrm{~h}$ on a table drier with cool air ventilation for $300 \mathrm{go} 400 \mathrm{~g} / \mathrm{kg}$ dry matter (DM), whereafter it was cut with a cutting machine (RP03, OPP Polička a.s., Czech Republic) to a theoretical length of 1.0 to $1.5 \mathrm{~cm}$ and ensiled, without additives, in hermetic glass vessels (3 L capacity). For each grass species and harvest time, two vessels were stored in a dark room at a temperature of $15{ }^{\circ} \mathrm{C}$ for storage periods of 10 and 20 weeks, respectively. At the opening the silages were analyzed for fermentation quality, i.e. $\mathrm{pH}$ (measured with a $\mathrm{pH}$ meter, WTW Level 1) and concentration of lactic, acetic and butyric acids, determined by isotachophoresis (Kvasnička, 2000) using an Ionosep 2001 apparatus (RECMAN Laboratory Systems, Ostrava, Czech Republic). Isotachophoresis is one of the basic electrophoretic techniques used based on injecting a sample solution between leading and terminating solutions present in the separation compartment. The leading electrolyte solution contains an anion or cation which has a higher effective mobility than those of the sample constituents to be analyzed. The terminating electrolyte solution contains an anion or cation of a lower effective mobility. The electric field was applied to separate the sample constituents (Kvasnička, 2000). The silage samples were subsequently oven-dried at $50{ }^{\circ} \mathrm{C}$ for $48 \mathrm{~h}$ and milled to pass a $1 \mathrm{~mm}$ screen.

All ensiled samples $(n=24)$ were analyzed for DM, crude protein $(C P)$, ash, ether extract $(E E), N D F$, acid detergent fibre (ADF) and acid detergent lignin (ADL). The residual moisture of the samples was determined at $105{ }^{\circ} \mathrm{C}$ for $12 \mathrm{~h}$ of oven-drying, and ash content was determined after combustion at $550{ }^{\circ} \mathrm{C}$ for $4.5 \mathrm{~h}$ (Regulation No. 497/2004, 2004). The EE level was determined, using the Soxtec extraction method with petroleum-ether (AOAC Official Method 920.39; AOAC, 2005). The Kjeldahl method was used for determining of nitrogen (N) (AOAC Official Method 976.05; AOAC, 2005), with the CP content

Table 1 Maturity stages ${ }^{1}$ of used grass for silage-making by harvest date

\begin{tabular}{llccc}
\hline \multirow{2}{*}{ Year } & Date & \multicolumn{3}{c}{ Grass species } \\
\cline { 3 - 5 } & & Dactylis glomerata & Festuca arundinacea & Hybrid Felina \\
\hline \multirow{2}{*}{2004} & 19 May & 35 & 31 & 38 \\
& 26 May & 51 & 32 & 50 \\
2005 & 27 May & 51 & 37 & 51 \\
& 10 June & 61 & 55 & 59
\end{tabular}

\footnotetext{
${ }^{1}$ Based on decimal code described by Zadoks et al. (1974) in which 30 to 39 refer to stem elongation, 50 to 59 to inflorescence emergence, and 60 to 69 to anthesis.
} 
calculated as $\mathrm{N} \times$ 6.25. Ash-free ADF and ADL were analyzed according to the AOAC Official Method 973.18 (AOAC, 2005). The NDF concentration (Van Soest et al., 1991) of samples and digested residues were analysed in the presence of sodium sulphite, but without $\alpha$-amylase treatment, and is presented as ashfree. All fibre analyses were performed in an ANKOM 220 Fiber Analyzer (ANKOM Technology Corporation, NY. USA).

In situ experiments complied with the guidelines of the Ministry of Agriculture of the Czech Republic (Act No 246/1992 Coll.) in respect of animal experimentation and the care of animals under study. For in situ analyses, two Holstein steers (live weight $800 \mathrm{~kg}$ ) fitted with rumen cannulas $(120 \mathrm{~mm}$ in inside diameter), were used. The animals had ad libitum access to meadow hay, and were fed twice a day with $1 \mathrm{~kg}$ of barley meal per animal. The meadow hay was made from growth, containing orchardgrass (Dactylis glomerata L.; 30\%), timothy (Phleum pratense L.; $20 \%$ ), meadow fescue (Festuca pratensis H.; 25\%), ryegrass (Lolium perenne L.; 10\%), white clover (Trifolium repens L.; 10\%) and herbs (5\%). For the in situ determination, the silage samples were oven-dried at $50{ }^{\circ} \mathrm{C}$ for $48 \mathrm{~h}$ and milled to pass a $1 \mathrm{~mm}$ screen. The rumen degradability of the NDF, in the experimental silages, was determined by incubating $1.5 \mathrm{~g}$ of each silage (in triplicate) in nylon bags (pore size $42 \mu \mathrm{m}$, internal dimensions $50 \times 120 \mathrm{~mm}$, Uhelon $130 \mathrm{~T}$, Silk and Progress Moravská Chrastová, Czech Republic) for 6, 12, 24, 48, 72 and $96 \mathrm{~h}$ in the rumen of the steers.

Indigestible NDF contents of the silage samples were determined by using a $288 \mathrm{~h}$ rumen incubation period (Rinne et al., 1997; Nousiainen et al., 2004). Nylon bags (Swiss Silk Bolting Cloth Ltd., Zurich, Switzerland; external dimensions $60 \times 120 \mathrm{~mm})$ with a small pore size $(17 \mu \mathrm{m})$, which minimize particle inflow and outflow but still ensure sufficient microbial activities inside the bags (Huhtanen et al., 1998; Nousiainen et al., 2003b), were used. Three grams of each sample were weighed into a bag and incubated in three replicates per animal. After incubation, the bags were rinsed by hand with cold water for 30 minutes and dried at $50{ }^{\circ} \mathrm{C}$ for $48 \mathrm{~h}$.

Parameters of NDF ruminal degradability $\left(\operatorname{Deg}_{(t)}\right)$ and effective degradability of NDF $\left(E_{\mathrm{NDF}}\right)$ were calculated according to equations adapted from Ørskov \& McDonald (1979):

$\operatorname{Deg}_{(\mathrm{t})}=b \times\left(1-\exp ^{-c t}\right) ; \mathrm{ED}_{\mathrm{NDF}}=b \times[c /(c+\mathrm{k})]$

where $b=$ fraction of NDF potentially degradable in the rumen, $c=$ rate constant of degradation of fraction $b$, $\mathrm{t}=$ time of incubation and $\mathrm{k}=$ ruminal outflow rate. $\mathrm{ED}_{\mathrm{NDF}}$ was estimated for each sample assuming ruminal solid outflow rates of $0.02,0.05$ and $0.08 / \mathrm{h}\left(\mathrm{ED}_{\mathrm{NDF} 2}, \mathrm{ED}_{\mathrm{NDF} 5}\right.$ and $\mathrm{ED}_{\mathrm{NDF} 8}$, respectively), which represent low, medium and high feed intakes, respectively (Petit \& Tremblay, 1992). The soluble fraction was omitted from the equations, as NDF is by definition insoluble.

The results for chemical composition (ash, EE, CP, NDF, ADF and ADL), rumen degradation parameters $\left(c, b, \mathrm{ED}_{\mathrm{NDF} 2}, \mathrm{ED}_{\mathrm{NDF} 5}\right.$ and $\left.\mathrm{ED}_{\mathrm{NDF} 8}\right)$ and INDF were analyzed using the MIXED procedure of SAS (SAS, 2002-2003). For the evaluation of rumen degradation parameters and INDF, grass species, year, storage period and animal were used as fixed effects, and harvest time nested within year used as a random effect. The grass species $\times$ year, grass species $\times$ storage period, year $\times$ storage period, grass species $\times$ animal, year $\times$ animal and storage period $\times$ animal interactions were included in the model. The data for chemical composition was analyzed with a similar model as described above, but with the animal effect excluded. Differences in mean values were evaluated by Scheffe's tests (Scheffé, 1953).

Correlation and simple linear regression were used for the evaluation of relationships within the parameters of chemical composition and utilization of NDF of the grass silages. Backward, stepwise, multiple regression analysis was applied to determine the best combination of chemical components for the prediction of $\mathrm{ED}_{\mathrm{NDF}}$ and INDF.

\section{Results and Discussion}

The chemical composition, fermentation quality, NDF ruminal degradation parameters and INDF of grass silages evaluated are presented in Table 2 . The values found in the present study showed a high variability in the chemical composition and degradability parameters, reflecting a wide range in NDF quality in the experimental silages. A wide variability is desired for developing prediction equations. The values of chemical composition are comparable to the results obtained by Huhtanen et al. (2002), Koukolová et al. (2004) and Nousiainen et al. (2004). Wilman et al. (2000) reported mean $b$ and $c$ values of $741 \mathrm{~g} / \mathrm{kg} \mathrm{NDF}$ and $0.048 / \mathrm{h}$, respectively, for NDF degradability of grass silages that contained $68 \mathrm{~g} / \mathrm{kg} \mathrm{DM}$ of lignin, whereas Spanghero et al. (2007) found $\mathrm{ED}_{\mathrm{NDF}}$ values of grass hay to vary from 239 to $483 \mathrm{~g} / \mathrm{kg} \mathrm{NDF}$ (k= $0.03 / \mathrm{h}$ ). A mean value of $860 \mathrm{~g} / \mathrm{kg}$ NDF for the potential digestibility of NDF, and $71.8 \mathrm{~g} / \mathrm{kg} \mathrm{DM}$ for INDF, 
was obtained for grass silage by Oba \& Allen (1999). According to Rinne et al. (2002), the INDF contents of grass silages harvested from 13 June to 4 July in Finland ranged from 48 to $124 \mathrm{~g} / \mathrm{kg} \mathrm{DM}$, and Lund et al. (2007) reported values of 49 and $137 \mathrm{~g} / \mathrm{kg}$ DM INDF for early and late cut grass silages, respectively.

The differences in chemical composition of grass species are indicated in Table 3. The highest CP content was found in $F$. arundinacea and the lowest $(P<0.05)$ in the hybrid Felina. The highest NDF content was detected in hybrid Felina $(P<0.05)$. A significantly higher mean value of ADF was detected in hybrid, Felina compared to $F$. arundinacea. No significant differences in content of ADL and EE were found in the different grass species. D. glomerata had the lowest $(P<0.05)$ level of ash. Similar to current results, Skládanka et al. (2008) detected a higher NDF content in the hybrid Felina, compared to D. glomerata. The same authors, however, stated a better quality (according to chemical composition) for the hybrid Felina, than for $F$. arundinacea. With the interactions between grass species $\times$ storage period and year $\times$ storage period being non-significant, both year and storage period, as main factors, did not present any differences $(P$ $>0.05)$. The interactions between grass species $\times$ year were different for ash, $\mathrm{CP}, \mathrm{NDF}$ and ADF $(P<0.05)$ (Table 6).

Table 2 Chemical composition, silage fermentation quality and NDF utilization of grass silages $(n=24)$

\begin{tabular}{|c|c|c|c|c|}
\hline & Mean & SD & Minimum & Maximum \\
\hline Dry matter (DM, g/kg) & 321 & 65.8 & 191 & 470 \\
\hline \multicolumn{5}{|l|}{ Silage chemical composition (g/kg DM) } \\
\hline Ash & 83.5 & 12.98 & 64.6 & 110 \\
\hline Ether extract (EE) & 29.2 & 4.43 & 20.0 & 38.6 \\
\hline Crude protein $(\mathrm{CP})$ & 149 & 35.9 & 93.7 & 214 \\
\hline Acid detergent fibre (ADF) & 331 & 35.3 & 253 & 386 \\
\hline Neutral detergent fibre (NDF) & 549 & 60.5 & 440 & 638 \\
\hline Acid detergent lignin (ADL) & 27.6 & 8.56 & 12.6 & 45.9 \\
\hline \multicolumn{5}{|l|}{ Parameters of fermentation process } \\
\hline $\mathrm{pH}$ & 4.65 & 0.378 & 4.04 & 5.33 \\
\hline Lactic acid (g/kg DM) & 24.7 & 11.19 & 8.11 & 64.4 \\
\hline Acetic acid (g/kg DM) & 6.66 & 3.819 & 3.00 & 18.3 \\
\hline Butyric acid (g/kg DM) & 1.41 & 3.012 & 0.00 & 11.4 \\
\hline Ammonia N (g/kg DM) & 0.36 & 0.120 & 0.20 & 0.62 \\
\hline \multicolumn{5}{|l|}{ Utilization of silages NDF } \\
\hline$b(\mathrm{~g} / \mathrm{kg} \mathrm{NDF})$ & 864 & 44.5 & 783 & 923 \\
\hline$c(/ \mathrm{h})$ & 0.036 & 0.0070 & 0.027 & 0.049 \\
\hline $\mathrm{ED}_{\mathrm{NDF} 2}(\mathrm{~g} / \mathrm{kg} \mathrm{NDF})$ & 549 & 52.6 & 463 & 643 \\
\hline $\mathrm{ED}_{\mathrm{NDF} 5}(\mathrm{~g} / \mathrm{kg} \mathrm{NDF})$ & 357 & 48.1 & 284 & 449 \\
\hline $\mathrm{ED}_{\mathrm{NDF} 8}(\mathrm{~g} / \mathrm{kg} \mathrm{NDF})$ & 264 & 41.0 & 204 & 345 \\
\hline INDF (g/kg DM) & 81.5 & 31.28 & 39.9 & 144 \\
\hline
\end{tabular}

$b$ - fraction of NDF potentially degradable in the rumen; $c$ - rate constant of disappearance of fraction $b$. $\mathrm{ED}_{\mathrm{NDF} 2}, \mathrm{ED}_{\mathrm{NDF5}}$ and $\mathrm{ED}_{\mathrm{NDF} 8}$ - effective degradability of $\mathrm{NDF}$ at rumen solid outflow rates of $0.02,0.05$ and $0.08 / \mathrm{h}$. INDF - indigestible neutral detergent fibre.

No significant interactions in grass species $\times$ storage period, grass species $\times$ animal, year $\times$ animal, storage period $\times$ animal and the animal effect were found for any of the parameters. Significant differences have been found in grass species regarding NDF degradation parameters $\left(b, c, \mathrm{ED}_{\mathrm{NDF}}\right)$ and INDF content (Table 4). Dactylis glomerata presented the lowest $(P<0.05)$ value for $b$ in comparison with $F$. arundinacea and hybrid Felina. The lowest $c$ value $(P<0.05)$ was found for hybrid Felina. The rate of NDF degradation 
(c) presented differences between year $(P<0.0001)$ (Table 5) and storage periods $(P=0.019)$ (Table 5). The $\mathrm{ED}_{\mathrm{NDF} 2}, \mathrm{ED}_{\mathrm{NDF} 5}$ and $\mathrm{ED}_{\mathrm{NDF} 8}$ were significantly higher after 20 weeks compared to 10 weeks of storage $(P$ $<0.001)$ (Table 5). At outflow rates of 0.05 and $0.08 / \mathrm{h}$, hybrid Felina presented the lowest $(P<0.05) \mathrm{ED}_{\mathrm{NDF}}$. The lowest $(P<0.05)$ content of INDF was found in $F$. arundinacea, whereas $D$. glomerata showed the highest numerical INDF content. However, it only differed significantly from $F$. arundinacea (Table 4$)$.

Table 3 Chemical composition $(\mathrm{g} / \mathrm{kg} \mathrm{DM})$ of silages as influenced by grass species $(\mathrm{n}=8$ per grass species)

\begin{tabular}{lcccccc}
\hline Grass species & Ash & EE & CP & NDF & ADF & ADL \\
\hline Dactylis glomerata & $76.6^{\mathrm{b}}$ & 30.8 & $149^{\mathrm{b}}$ & $541^{\mathrm{b}}$ & $333^{\mathrm{ab}}$ & 31.2 \\
Festuca arundinacea & $85.9^{\mathrm{a}}$ & 27.6 & $178^{\mathrm{a}}$ & $512^{\mathrm{b}}$ & $311^{\mathrm{b}}$ & 26.6 \\
Hybrid Felina & $87.8^{\mathrm{a}}$ & 29.2 & $119^{\mathrm{c}}$ & $595^{\mathrm{a}}$ & $349^{\mathrm{a}}$ & 25.1 \\
SE & 3.69 & 1.59 & 14.2 & 28.5 & 15.3 & 3.82
\end{tabular}

$\overline{\mathrm{a}-\mathrm{c}}$ Within a column, means without a common superscript differ $(P<0.05)$.

DM - dry matter; EE - ether extract; CP - crude protein; ADF - acid detergent fibre; NDF - neutral detergent fibre;

$\mathrm{ADL}$ - acid detergent lignin; SE - standard error.

Table 4 Rumen neutral detergent fibre (NDF) degradability and indigestible neutral detergent fibre content of silages as influenced by grass species ( $n=8$ per grass species)

\begin{tabular}{lcccccc}
\hline Grass species & $b$ & $c$ & $\mathrm{ED}_{\mathrm{NDF} 2}$ & $\mathrm{ED}_{\mathrm{NDF} 5}$ & $\mathrm{ED}_{\text {NDF8 }}$ & INDF \\
\hline Dactylis glomerata & $847^{\mathrm{b}}$ & $0.038^{\mathrm{a}}$ & $550^{\mathrm{ab}}$ & $363^{\mathrm{a}}$ & $271^{\mathrm{a}}$ & $86.9^{\mathrm{a}}$ \\
Festuca arundinacea & $874^{\mathrm{a}}$ & $0.037^{\mathrm{a}}$ & $560^{\mathrm{a}}$ & $366^{\mathrm{a}}$ & $272^{\mathrm{a}}$ & $73.1^{\mathrm{b}}$ \\
Hybrid Felina & $871^{\mathrm{a}}$ & $0.033^{\mathrm{b}}$ & $537^{\mathrm{b}}$ & $341^{\mathrm{b}}$ & $250^{\mathrm{b}}$ & $84.5^{\mathrm{a}}$ \\
SE & 24.1 & 0.0007 & 16.7 & 11.5 & 8.82 & 15.26 \\
\hline
\end{tabular}

${ }^{\mathrm{a}, \mathrm{b}}$ Within a column, means without a common superscript differ $(P<0.05)$.

$b$ - fraction of NDF potentially degradable in the rumen ( $/ \mathrm{kg}$ NDF); $c$ - rate constant of disappearance of fraction $b$ (/h); $\mathrm{ED}_{\mathrm{NDF} 2}, \mathrm{ED}_{\mathrm{NDF} 5}$ and $\mathrm{ED}_{\mathrm{NDF} 8}$ - effective degradability of NDF $(\mathrm{g} / \mathrm{kg} \mathrm{NDF})$ assuming rumen solid outflow rates of $0.02,0.05$ and $0.08 / \mathrm{h}$; INDF - indigestible neutral detergent fibre (g/kg DM); SE - standard error.

Table 5 Differences of parameters describing utilization of silages' neutral detergent fibre (NDF) evaluated between years and between storage periods

\begin{tabular}{|c|c|c|c|c|c|c|}
\hline & \multicolumn{2}{|c|}{ Year } & \multirow{2}{*}{ SE } & \multicolumn{2}{|c|}{ Storage period (weeks) } & \multirow{2}{*}{ SE } \\
\hline & 2004 & 2005 & & 10 & 20 & \\
\hline$b(\mathrm{~g} / \mathrm{kg} \mathrm{NDF})$ & 881 & 847 & 33.8 & 863 & 865 & 24.0 \\
\hline$c\left(\mathrm{~h}^{-1}\right)$ & $0.041^{\mathrm{b}}$ & $0.030^{\mathrm{a}}$ & 0.0006 & $0.034^{\mathrm{a}}$ & $0.037^{\mathrm{b}}$ & 0.0006 \\
\hline $\mathrm{ED}_{\mathrm{NDF} 2}(\mathrm{~g} / \mathrm{kg} \mathrm{NDF})$ & 589 & 509 & 23.3 & $542^{\mathrm{a}}$ & $556^{\mathrm{b}}$ & 16.6 \\
\hline $\mathrm{ED}_{\mathrm{NDF} 5}(\mathrm{~g} / \mathrm{kg} \mathrm{NDF})$ & 394 & 319 & 15.9 & $349^{\mathrm{a}}$ & $364^{\mathrm{b}}$ & 11.4 \\
\hline $\mathrm{ED}_{\mathrm{NDF} 8}(\mathrm{~g} / \mathrm{kg} \mathrm{NDF})$ & 297 & 232 & 12.0 & $258^{\mathrm{a}}$ & $271^{\mathrm{b}}$ & 8.65 \\
\hline INDF ( $\mathrm{g} / \mathrm{kg}$ DM) & 62.7 & 100 & 21.5 & 82.2 & 80.8 & 15.2 \\
\hline
\end{tabular}

${ }^{\mathrm{a}, \mathrm{b}}$ Within a row, means without a common superscript differ $(P<0.05)$.

$b$ - fraction of NDF potentially degradable in the rumen $(\mathrm{g} / \mathrm{kg}$ NDF); $c$ - rate constant of disappearance of fraction $b$ $(/ \mathrm{h}) ; \mathrm{ED}_{\mathrm{NDF} 2}, \mathrm{ED}_{\mathrm{NDF} 5}$ and $\mathrm{ED}_{\mathrm{NDF} 8}$ - effective degradability of NDF (g/kg NDF) assuming rumen solid outflow rates of $0.02,0.05$ and $0.08 / \mathrm{h}$; INDF - indigestible neutral detergent fibre (g/kg DM); SE - standard error. 
Table 6 Differences in chemical composition and parameters describing utilization of silages' neutral detergent fibre $(\mathrm{NDF})$ evaluated for grass species $\times$ year interaction

\begin{tabular}{|c|c|c|c|c|c|c|c|}
\hline \multirow{2}{*}{$\begin{array}{l}\text { Year } \\
\text { Grass }\end{array}$} & \multicolumn{3}{|c|}{2004} & \multicolumn{3}{|c|}{2005} & \multirow{2}{*}{ SE } \\
\hline & $\mathrm{D}$ & $\mathrm{F}$ & $\mathrm{H}$ & D & $\mathrm{F}$ & $\mathrm{H}$ & \\
\hline \multicolumn{8}{|c|}{ Silage chemical composition (g/kg dry matter, DM) } \\
\hline Ash & $71.7^{\mathrm{ab}}$ & $71.4^{\mathrm{ab}}$ & $79.3^{\mathrm{ab}}$ & $81.6^{\mathrm{a}}$ & $100^{\mathrm{b}}$ & $96.4^{\mathrm{b}}$ & 5.22 \\
\hline Ether extract & 31.5 & 26.2 & 26.3 & 30.1 & 29.0 & 32.0 & 2.25 \\
\hline Crude protein & $166^{\text {bde }}$ & $198^{\text {cde }}$ & $117^{\text {ade }}$ & $132^{\mathrm{abcd}}$ & $158^{\text {abce }}$ & $120^{\mathrm{abcd}}$ & 20.1 \\
\hline NDF & $527^{\mathrm{a}}$ & $479^{\mathrm{a}}$ & $608^{\mathrm{b}}$ & $556^{\mathrm{ab}}$ & $545^{\mathrm{ab}}$ & $582^{\mathrm{ab}}$ & 40.3 \\
\hline $\mathrm{ADF}$ & $323^{\mathrm{b}}$ & $278^{\mathrm{a}}$ & $356^{\mathrm{b}}$ & $343^{\mathrm{ab}}$ & $344^{\mathrm{ab}}$ & $342^{\mathrm{ab}}$ & 21.6 \\
\hline $\mathrm{ADL}$ & 29.1 & 21.1 & 20.0 & 33.2 & 32.1 & 30.2 & 5.40 \\
\hline \multicolumn{8}{|c|}{ Utilization of silages NDF } \\
\hline$b(\mathrm{~g} / \mathrm{kg} \mathrm{NDF})$ & $850^{\mathrm{a}}$ & $907^{\mathrm{b}}$ & $888^{\mathrm{b}}$ & $843^{\mathrm{ab}}$ & $842^{\mathrm{ab}}$ & $855^{\mathrm{ab}}$ & 34.1 \\
\hline$c(/ \mathrm{h})$ & $0.044^{\mathrm{c}}$ & $0.044^{\mathrm{c}}$ & $0.035^{\mathrm{b}}$ & $0.032^{\mathrm{b}}$ & $0.030^{\mathrm{a}}$ & $0.030^{\mathrm{a}}$ & 0.001 \\
\hline $\mathrm{ED}_{\mathrm{NDF} 2}(\mathrm{~g} / \mathrm{kg} \mathrm{NDF})$ & $585^{\mathrm{a}}$ & $620^{\mathrm{b}}$ & $562^{\mathrm{b}}$ & $515^{\mathrm{ab}}$ & $500^{\mathrm{a}}$ & $512^{\mathrm{a}}$ & 23.6 \\
\hline $\mathrm{ED}_{\mathrm{NDF} 5}(\mathrm{~g} / \mathrm{kg} \mathrm{NDF})$ & $399^{\mathrm{b}}$ & $421^{\mathrm{b}}$ & $363^{\mathrm{a}}$ & $326^{\mathrm{a}}$ & $311^{\mathrm{a}}$ & $319^{\mathrm{a}}$ & 16.3 \\
\hline $\mathrm{ED}_{\mathrm{NDF} 8}(\mathrm{~g} / \mathrm{kg} \mathrm{NDF})$ & $303^{\mathrm{b}}$ & $319^{\mathrm{b}}$ & $268^{\mathrm{a}}$ & $239^{\mathrm{a}}$ & $226^{\mathrm{a}}$ & $232^{\mathrm{a}}$ & 12.5 \\
\hline INDF (g/kg DM) & $71.8^{\mathrm{b}}$ & $44.5^{\mathrm{a}}$ & $72.0^{\mathrm{b}}$ & $102^{\mathrm{ab}}$ & $102^{\mathrm{ab}}$ & $97.0^{\mathrm{ab}}$ & 21.6 \\
\hline
\end{tabular}

${ }^{\mathrm{a}-\mathrm{e}}$ Within a row means without a common superscript differ $(P<0.05)$.

D - Dactylis glomerata L.; F - Festuca arundinacea L.; H - hybrid Felina; ADF - acid detergent fibre; NDF - neutral detergent fibre; ADL - acid detergent lignin; $b$ - fraction of NDF potentially degradable in the rumen (g/kg NDF); $c$ rate constant of disappearance of fraction $b(/ \mathrm{h}) ; \mathrm{ED}_{\mathrm{NDF} 2}, \mathrm{ED}_{\mathrm{NDF} 5}$ and $\mathrm{ED}_{\mathrm{NDF} 8}$ - effective degradability of $\mathrm{NDF}(\mathrm{g} / \mathrm{kg}$ $\mathrm{NDF}$ ) assuming rumen solid outflow rates of $0.02,0.05$ and $0.08 / \mathrm{h}$; INDF - indigestible neutral detergent fibre $(\mathrm{g} / \mathrm{kg}$ $\mathrm{DM})$; SE - standard error.

A faster rate of NDF degradation $(c)$ detected after the longer storage period (20 weeks) $(P=0.001$; $\mathrm{SE}=0.0006)$ influenced the calculated $\mathrm{ED}_{\mathrm{NDF}}$ values $(P=0.0005,0.0003$ and $0.0003 ; \mathrm{SE}=16.6,11.4$ and 8.7 for $\mathrm{ED}_{\mathrm{NDF} 2}, \mathrm{ED}_{\mathrm{NDF} 5}$ and $\mathrm{ED}_{\mathrm{NDF} 8}$, respectively) (Table 5). This could be attributed to the shortening of the cellulose chain length as a result of extra-cellular cellulase activity from silage microflora and hydrolysis of hemicellulose by organic acids produced during fermentation (Yahaya et al., 2001). Cell walls, subjected to silage processing and microorganisms, may be more susceptible to enzymatic attack, mainly in early periods of fermentation in the rumen. Comparable to current results, NDF digestibility of $F$. arundinacea was found by Pozdíšek et al. (2003) to be higher than for the festulolium hybrid Hykor. Presented differences of ED $_{\mathrm{NDF}}$ in the different grass species are in agreement with our results on the in situ degradation of DM (Jančík et al., 2009), where $F$. arundinacea had higher mean values of DM effective degradability than D. glomerata and hybrid Felina. Differences in grass species might be related to the differences in maturity of the observed grass (Table 1). D. glomerata and hybrid Felina are early maturing grass species, whereas $F$. arundinacea is a late-maturing grass. In the present study differences were found for interactions between grass species $\times$ year and year $\times$ storage period. The differences for interactions between grass species $\times$ year detected for all degradability parameters and INDF $(P<0.0001)$ are presented in the Table 6 . The interactions between year $\times$ storage period were different for parameter $c, \mathrm{ED}_{\mathrm{NDF} 2}, \mathrm{ED}_{\mathrm{NDF} 5}$ and $\mathrm{ED}_{\mathrm{NDF} 8}(P<0.001)$ (Table 7).

The correlation coefficients ( $\mathrm{r}$ ) of the relationships between chemical composition and parameters of NDF degradation $\left(b, c, \mathrm{ED}_{\mathrm{NDF} 2}, \mathrm{ED}_{\mathrm{NDF} 5}\right.$ and $\left.\mathrm{ED}_{\mathrm{NDF} 8}\right)$ and INDF are given in Table 8. Parameter $b$ was the highest $(P<0.05)$ correlated to ADL, and the lowest to ash. The lower ash content was found for silages made from younger grasses. It means that these silages had a higher OM content, and a higher OM content can lead to faster digestibility of feeds, especially with regard to the lower lignification of younger grasses. The correlation coefficient between $c$ and ash $(\mathrm{r}=-0.73)$ shows that faster degraded silages had a lower ash content. In contrast, parameter $c$ was the highest $(P<0.05)$ correlated to ash, and the lowest to EE. The 
highest correlations of $\mathrm{ED}_{\mathrm{NDF}}$ and INDF were found in $\mathrm{ADF}(P<0.05)$, whereas these measurements presented low correlations with EE.

Table 7 Differences of parameters describing utilization of silages' neutral detergent fibre (NDF) evaluated for year $\times$ storage period interaction

\begin{tabular}{|c|c|c|c|c|c|}
\hline \multirow{2}{*}{$\begin{array}{r}\text { Year } \\
\text { Storage period (weeks) }\end{array}$} & \multicolumn{2}{|c|}{2004} & \multicolumn{2}{|c|}{2005} & \multirow{2}{*}{ SE } \\
\hline & 10 & 20 & 10 & 20 & \\
\hline$b(\mathrm{~g} / \mathrm{kg} \mathrm{NDF})$ & 883 & 880 & 843 & 850 & 34.0 \\
\hline$c(/ \mathrm{h})$ & $0.034^{\mathrm{b}}$ & $0.044^{\mathrm{c}}$ & $0.044^{\mathrm{d}}$ & $0.031^{\mathrm{a}}$ & 0.0008 \\
\hline $\mathrm{ED}_{\mathrm{NDF} 2}(\mathrm{~g} / \mathrm{kg} \mathrm{NDF})$ & $574^{\mathrm{a}}$ & $604^{b}$ & $509^{\mathrm{ab}}$ & $509^{\mathrm{ab}}$ & 23.5 \\
\hline $\mathrm{ED}_{\mathrm{NDF} 5}(\mathrm{~g} / \mathrm{kg} \mathrm{NDF})$ & $378^{\mathrm{a}}$ & $411^{\mathrm{b}}$ & $320^{\mathrm{a}}$ & $318^{\mathrm{a}}$ & 16.1 \\
\hline $\mathrm{ED}_{\mathrm{NDF} 8}(\mathrm{~g} / \mathrm{kg} \mathrm{NDF})$ & $282^{\mathrm{a}}$ & $311^{\mathrm{b}}$ & $233^{\mathrm{a}}$ & $231^{\mathrm{a}}$ & 12.2 \\
\hline INDF (g/kg DM) & 64.0 & 61.4 & 100 & 100 & 21.5 \\
\hline
\end{tabular}

${ }^{\mathrm{a}-\mathrm{d}}$ Within a row, means without a common superscript differ $(P<0.05)$.

$b$ - fraction of NDF potentially degradable in the rumen ( $\mathrm{g} / \mathrm{kg} \mathrm{NDF}) ; c$ - rate constant of disappearance of fraction $b$ (/h); $\mathrm{ED}_{\mathrm{NDF} 2}, \mathrm{ED}_{\mathrm{NDF} 5}$ and $\mathrm{ED}_{\mathrm{NDF}}$ - effective degradability of NDF $(\mathrm{g} / \mathrm{kg} \mathrm{NDF})$ assuming rumen solid outflow rates of $0.02,0.05$ and $0.08 / \mathrm{h}$; INDF - indigestible neutral detergent fibre (g/kg DM); SE - standard error.

Table 8 Linear correlation coefficients between chemical components and fibre-related measurements $(n=24)$

\begin{tabular}{|c|c|c|c|c|c|c|}
\hline Parameter & Ash & $\begin{array}{l}\text { Ether extract } \\
\text { (EE) }\end{array}$ & $\begin{array}{l}\text { Crude protein } \\
\text { (CP) }\end{array}$ & $\begin{array}{l}\text { Acid detergent } \\
\text { fibre (ADF) }\end{array}$ & $\begin{array}{l}\text { Neutral detergent } \\
\text { fibre (NDF) }\end{array}$ & $\begin{array}{l}\text { Acid detergent } \\
\text { lignin (ADL) }\end{array}$ \\
\hline EE & 0.18 & & & & & \\
\hline $\mathrm{CP}$ & -0.11 & -0.06 & & & & \\
\hline $\mathrm{ADF}$ & 0.18 & 0.10 & $-0.86^{*}$ & & & \\
\hline NDF & 0.05 & 0.02 & $-0.92^{*}$ & $0.93^{*}$ & & \\
\hline $\mathrm{ADL}$ & 0.08 & 0.33 & $-0.41^{*}$ & $0.54^{*}$ & $0.42^{*}$ & \\
\hline$b$ & 0.04 & -0.12 & $0.62^{*}$ & $-0.68^{*}$ & $-0.61^{*}$ & $-0.80^{*}$ \\
\hline$c$ & $-0.73^{*}$ & -0.01 & $0.56^{*}$ & $-0.59^{*}$ & $-0.48^{*}$ & -0.30 \\
\hline $\mathrm{ED}_{\mathrm{NDF} 2}$ & $-0.51^{*}$ & -0.08 & $0.72^{*}$ & $-0.78^{*}$ & $-0.65^{*}$ & $-0.65^{*}$ \\
\hline $\mathrm{ED}_{\mathrm{NDF} 5}$ & $-0.60^{*}$ & -0.07 & $0.69^{*}$ & $-0.74^{*}$ & $-0.62^{*}$ & $-0.56^{*}$ \\
\hline $\mathrm{ED}_{\mathrm{NDF} 8}$ & $-0.63^{*}$ & -0.06 & $0.68^{*}$ & $-0.72^{*}$ & $-0.60^{*}$ & $-0.52^{*}$ \\
\hline INDF & 0.21 & 0.10 & $-0.75^{*}$ & $0.83^{*}$ & $0.74^{*}$ & $0.78^{*}$ \\
\hline
\end{tabular}

${ }^{*} P<0.05 ; b$ - fraction of NDF potentially degradable in the rumen (g/kg NDF); $c$ - rate constant of disappearance of fraction $b(/ \mathrm{h}) ; \mathrm{ED}_{\mathrm{NDF} 2}, \mathrm{ED}_{\mathrm{NDF} 5}$ and $\mathrm{ED}_{\mathrm{NDF} 8}$ - effective degradability of $\mathrm{NDF}(\mathrm{g} / \mathrm{kg} \mathrm{NDF})$ assuming rumen solid outflow rates of $0.02,0.05$ and $0.08 / \mathrm{h}$; INDF - indigestible neutral detergent fibre $(\mathrm{g} / \mathrm{kg} \mathrm{DM})$.

In agreement with the current study, Hoffman et al. (1993) presented r-values of $-0.32,0.60$ and 0.50 between $\mathrm{ADL}$ and $\mathrm{CP}, \mathrm{ED}_{\mathrm{NDF}}$ and $\mathrm{CP}$, and $\mathrm{ED}_{\mathrm{NDF}}$ and $\mathrm{ADL}$, respectively. Andrés et al. (2005) found a high correlation between $b$ and CP $(\mathrm{r}=0.65)$, and NDF degradability after a 96-h incubation period and CP $(\mathrm{r}=$ 0.80). Significant correlations of $-0.82,-0.78,-0.78$ and 0.88 were reported (Koukolová et al., 2004; Jančík et al., 2008) between $b$ and ADL, $c$ and NDF, $c$ and ADF, and INDF and ADL, respectively. Several authors (Traxler et al., 1998; Jančík et al., 2008) used ADL content as the most reliable variable to predict the INDF content of grass. According to Grenet \& Besle (1991) and Nagadi et al. (2000) degradability of cell wall 
carbohydrates is mainly limited by lignin content, accentuating its influence on feed utilization (Ahmad \& Wilman, 2001). Bosch \& Bruining (1995) confirmed that grass silages, with a high lignin content, have a lower digestibility compared to silages that contained low levels of lignin. Traxler et al. (1998) found an important relationship $(\mathrm{r}=0.81)$ between INDF and the lignin content in the different type of grass. This was confirmed by a high negative $r$ value $(-0.80)$ between the NDF digestibility and ADL content of legumes and grasses by Jung et al. (1997).

The most reliable combinations of chemical components $(\mathrm{CP}, \mathrm{NDF}, \mathrm{ADF}, \mathrm{ADL})$ to predict $\mathrm{ED}_{\mathrm{NDF}}$, $\mathrm{ED}_{\mathrm{NDF} 5}, \mathrm{ED}_{\mathrm{NDF} 8}$ and INDF, calculated by backward, stepwise, multiple regression analysis, are presented in Table 9. A multiple regression analysis was used because of the low predictability of equations determined with simple linear regression and one predictor $\left(\mathrm{R}^{2}=0.272\right.$ to 0.689$)$ (Table 10). For $\mathrm{ED}_{\mathrm{NDF} 5}, \mathrm{ED}_{\mathrm{NDF}}$ and INDF the lowest residual mean square error (RMSE) was obtained with a combination of three or four predictors. The $\mathrm{ED}_{\mathrm{NDF} 2}$ had the lowest RMSE when a combination of four predictors was used. However, the RMSE value derived from the use of two predictors for INDF and three predictors for $\mathrm{ED}_{\mathrm{NDF} 2}$ did not differ substantially from the use of four predictors. The combination of CP, ADF and NDF was identified as the most suitable predictor for $\mathrm{ED}_{\mathrm{NDF} 2}, \mathrm{ED}_{\mathrm{NDF} 5}$ and $\mathrm{ED}_{\mathrm{NDF} 8}$, whereas $\mathrm{ADF}$ and $\mathrm{NDF}$ also predicted $\mathrm{ED}_{\mathrm{NDF} 2}$, $\mathrm{ED}_{\mathrm{NDF} 5}$ and $\mathrm{ED}_{\mathrm{NDF} 8}$ with an acceptable degree of accuracy. The combination of ADF and ADL was found to predict INDF accurately. However, an $\mathrm{R}^{2}$-value of 0.689 showed that ADF can be used as a single predictor for INDF. Jančík et al. (2010) reported that the combination of ADF and NDF was the most suitable predictor for $\mathrm{ED}_{\mathrm{NDF}}$ of dried $F$. arundinacea $\left(\mathrm{R}^{2}=0.941, \mathrm{RMSE}=18.3\right)$.

Table 9 Best-fit combinations of chemical components to predict neutral detergent fibre effective degradability and indigestible neutral detergent fibre content when applying backward, stepwise, multiple regression $(n=24)$

\begin{tabular}{|c|c|c|c|c|c|c|c|}
\hline & Constant & $\mathrm{CP}$ & $\mathrm{ADF}$ & NDF & ADL & RMSE & $\mathrm{R}^{2}$ \\
\hline \multirow{3}{*}{$\mathrm{ED}_{\mathrm{NDF} 2}$} & $461_{(193.4)}$ & $0.97_{(0.412)}$ & $-1.38_{(0.505)}$ & $-0.81_{(0.346)}$ & $-1.71_{(0.835)}$ & 27.9 & 0.767 \\
\hline & $470_{(208.2)}$ & $1.00_{(0.443)}$ & $-1.83_{(0.488)}$ & $-0.97_{(0.362)}$ & & 30.1 & 0.715 \\
\hline & $922_{(65.0)}$ & & $-1.90_{(0.533)}$ & $0.47_{(0.311)}$ & & 32.9 & 0.642 \\
\hline \multirow{3}{*}{$\mathrm{ED}_{\mathrm{NDF} 5}$} & $241_{(205.4)}$ & $0.95_{(0.437)}$ & $-1.40_{(0.536)}$ & $-0.85_{(0.367)}$ & $-0.91_{(0.887)}$ & 29.7 & 0.686 \\
\hline & $246_{(205.5)}$ & $0.96_{(0.438)}$ & $-1.64_{(0.482)}$ & $-0.93_{(0.358)}$ & & 29.7 & 0.669 \\
\hline & $680_{(63.8)}$ & & $-1.71_{(0.523)}$ & $0.44_{(0.306)}$ & & 32.3 & 0.588 \\
\hline \multirow{3}{*}{$\mathrm{ED}_{\mathrm{NDF} 8}$} & $157_{(182.4)}$ & $0.82_{(0.389)}$ & $-1.22_{(0.476)}$ & $0.74_{(0.326)}$ & $-0.59_{(0.788)}$ & 26.4 & 0.658 \\
\hline & $160_{(180.3)}$ & $0.83_{(0.384)}$ & $-1.38_{(0.423)}$ & $0.80_{(0.314)}$ & & 26.1 & 0.648 \\
\hline & $534_{(55.8)}$ & & $-1.44_{(0.456)}$ & $0.38_{(0.267)}$ & & 28.3 & 0.566 \\
\hline \multirow{3}{*}{ INDF } & $21.5_{(86.18)}$ & $-0.35_{(0.086)}$ & $0.49_{(0.225)}$ & $-0.17_{(0.154)}$ & $1.68_{(0.372)}$ & 12.5 & 0.869 \\
\hline & $-36.5_{(69.75)}$ & $-0.22_{(0.146)}$ & $0.31_{(0.161)}$ & & $1.78_{(0.365)}$ & 12.5 & 0.860 \\
\hline & $-136_{(26.0)}$ & & $0.51_{(0.090)}$ & & $1.70_{(0.373)}$ & 12.9 & 0.844 \\
\hline
\end{tabular}

Values in subscript parentheses are SE; RMSE - residual mean square error; CP - crude protein; ADF - acid detergent fibre; NDF - neutral detergent fibre; $\mathrm{ADL}$ - acid detergent lignin; $\mathrm{ED}_{\mathrm{NDF} 2}, \mathrm{ED}_{\mathrm{NDF}}$ and $\mathrm{ED}_{\mathrm{NDF} 8}$ - effective degradability of NDF (g/kg NDF) assuming rumen solid outflow rates of $0.02,0.05$ and $0.08 / \mathrm{h}$; INDF - indigestible neutral detergent fibre $(\mathrm{g} / \mathrm{kg} \mathrm{DM})$.

Chemical parameters as predictors of digestion become complicated when plant types such as legumes or gramineae are studied (Khazaal et al., 1995). Although empirical equations have not been proven to be successful in determining DM digestibility (Khazaal et al., 1995) or OM digestibility (Huhtanen et al., 2006) from fibre components, the current study shows that prediction equations based on chemical components can produce equations with acceptable accuracy for NDF digestibility. However, it should be emphasized that equations have to be restricted to forage type and harvest stage. 
The content of ADF was the best single predictor of $\mathrm{ED}_{\mathrm{NDF}}$ and INDF (Table 10). However, a better prediction equation for INDF was found when using a combination of ADF and ADL (Table 9). This could be attributed to the fact that lignin is regarded as the principal factor limiting digestibility, although it does not affect all feed components. Non-cell wall components are not influenced by lignin, but they can often be highly correlated. Therefore, lignin concentration affects mainly the availability of cell wall polysaccharides (Van Soest, 1994). Cellulose, which along with lignin forms ADF, reduces the digestion rate and extent of digestion which are related to the lignin content. Hemicellulose (presenting NDF along with cellulose and lignin) is closely associated with lignin, and the digestibility of hemicellulose is directly related to that of cellulose and inversely related to lignification (Van Soest, 1994). In the present study, a combination of CP, $\mathrm{ADF}$ and NDF gave the best equations for $\mathrm{ED}_{\mathrm{NDF}}$ based on three predictors. The higher effect of $\mathrm{CP}$ on $\mathrm{ED}_{\mathrm{NDF}}$ was caused by the influence of parameter $c$ in the calculation of $\mathrm{ED}_{\mathrm{NDF}}$. A high correlation between $\mathrm{CP}$ and parameter $c$ most likely occurred because of a co-association when protein declines as grass matures and lignification proceeds (Van Soest, 1994; Nousiainen et al., 2003a). Neutral detergent fibre represents the total insoluble matrix fibre, and it is better related to rumination and passage compared to other chemical components. Acid detergent fibre does not represent all insoluble fibre, but it is frequently better correlated with digestibility than NDF (Van Soest, 1994).

Table 10 Prediction of neutral detergent fibre effective degradability and indigestible neutral detergent fibre content using simple linear regression $(n=24)$

\begin{tabular}{|c|c|c|c|c|c|c|c|}
\hline & Constant & $\mathrm{CP}$ & $\mathrm{ADF}$ & NDF & ADL & RMSE & $\mathrm{R}^{2}$ \\
\hline \multirow{4}{*}{$\mathrm{ED}_{\mathrm{NDF} 2}$} & $393_{(33.2)}$ & $1.05_{(0.218)}$ & \multirow{4}{*}{$-1.16_{(0.200)}$} & & & 37.4 & 0.515 \\
\hline & $932_{(66.4)}$ & & & & & 33.8 & 0.604 \\
\hline & $861_{(77.6)}$ & & & $-0.57_{(0.140)}$ & & 40.8 & 0.426 \\
\hline & $660_{(28.6)}$ & & & & $-4.00_{(0.993)}$ & 40.8 & 0.425 \\
\hline \multirow{4}{*}{$\mathrm{ED}_{\mathrm{NDF} 5}$} & $219_{(31.7)}$ & $0.92_{(0.207)}$ & \multirow{4}{*}{$-1.01_{(0.195)}$} & & & 35.7 & 0.474 \\
\hline & $690_{(65.0)}$ & & & & & 33.1 & 0.547 \\
\hline & $625_{(73.9)}$ & & & $-0.49_{(0.134)}$ & & 38.8 & 0.378 \\
\hline & $443_{(28.7)}$ & & & & $-3.12_{(0.996)}$ & 40.9 & 0.309 \\
\hline \multirow{4}{*}{$\mathrm{ED}_{\mathrm{NDF} 8}$} & $150_{(27.4)}$ & $0.77_{(0.179)}$ & \multirow{4}{*}{$-0.84_{(0.170)}$} & & & 30.8 & 0.458 \\
\hline & $542_{(56.7)}$ & & & & & 28.9 & 0.525 \\
\hline & $488_{(63.8)}$ & & & $-0.41_{(0.115)}$ & & 33.5 & 0.362 \\
\hline & $333_{(25.1)}$ & & & & $-2.50_{(0.870)}$ & 35.7 & 0.272 \\
\hline \multirow{4}{*}{ INDF } & $179_{(18.6)}$ & $-0.66_{(0.122)}$ & \multirow{4}{*}{$0.74_{(0.105)}$} & & & 21.0 & 0.569 \\
\hline & $-162_{(35.0)}$ & & & & & 17.8 & 0.689 \\
\hline & $-128_{(41.2)}$ & & & $0.38_{(0.075)}$ & & 21.6 & 0.543 \\
\hline & $-3.08_{(14.151)}$ & & & & $2.84_{(0.490)}$ & 20.1 & 0.604 \\
\hline
\end{tabular}

Values in subscript parentheses are SE.; RMSE - residual mean square error; CP - crude protein; ADF - acid detergent fibre; NDF - neutral detergent fibre; ADL - acid detergent lignin; $\mathrm{ED}_{\mathrm{NDF} 2}, \mathrm{ED}_{\mathrm{NDF} 5}$ and $\mathrm{ED}_{\mathrm{NDF}}$ - effective degradability of NDF ( $/ \mathrm{kg} \mathrm{NDF}$ ) assuming rumen solid outflow rates of $0.02,0.05$ and $0.08 / \mathrm{h}$; INDF - indigestible neutral detergent fibre $(\mathrm{g} / \mathrm{kg} \mathrm{DM})$.

\section{Conclusions}

According to parameters describing NDF utilization, all tested types of grass are suitable forages to be ensiled for ruminant nutrition. However, D. glomerata and hybrid Felina, should be harvested earlier because of their rapid maturing rate. $F$. arundinacea matures more slowly and thus provides a high-quality forage for a longer vegetative period. This study confirmed that the $\mathrm{ED}_{\mathrm{NDF}}$ and the INDF content of grass silages could 
be effectively predicted from a combination of two or three chemical components. Based on the current results, the use of a combination of $\mathrm{CP}, \mathrm{ADF}$ and $\mathrm{NDF}$ for prediction of $\mathrm{ED}_{\mathrm{NDF}}$, and $\mathrm{ADF}$ and $\mathrm{ADL}$ for prediction of INDF, can be suggested. These equations could replace laborious and time-consuming in situ and in vivo techniques to evaluate the nutritional quality of feeds for ruminants. However, more research is needed on the relationships between NDF rumen degradation parameters (including INDF) and chemical components for silages made of legumes, maize, regrowth grass and whole grain cereals.

\section{Acknowledgements}

This work was supported financially by the Ministry of Agriculture of the Czech Republic (Project No. MZE0002701404).

\section{References}

Ahmad, N. \& Wilman, D., 2001. The degradation of the cell walls of lucerne, Italian ryegrass and wheat straw when fed to cattle, sheep and rabbits. J. Agric. Sci. 137, 337-349.

Andrés, S., Giráldez, F.J., González, J.S., Paláez, R., Prieto, N. \& Calleja, A., 2005. Prediction of aspects of neutral detergent fibre digestion of forages by chemical composition and near infrared reflectance spectroscopy. Aust. J. Agric. Res. 56, 187-193.

AOAC, 2005. Official Methods of Analysis, AOAC International. $18^{\text {th }}$ ed. Gaithersburg, USA, ISBN 0-935584-75-7.

Bosch, M.W. \& Bruining, M., 1995. Passage rate and total clearance rate from the rumen of cows fed on grass silages differing in cell-wall content. Br. J. Nutr. 73, 41-49.

Cherney, D.J.R., Cherney, J.H. \& Lucey, R.F., 1993. In vitro digestion kinetics and quality of perennial grasses as influenced by forage maturity. J. Dairy Sci. 76, 790-797.

Grenet, E. \& Besle, J.M., 1991. Microbes and fibre degradation. In: Rumen Microbial Metabolism and Ruminant Digestion. Ed. Jouany, J.P., Institut national de la recherche agronomique, Paris, France, 107-129.

Hackmann, T.J., Sampson, J.D. \& Spain, J.N., 2008. Comparing relative feed value with degradation parameters of grass and legume forages. J. Anim. Sci. 86, 2344-2356.

Hoffman, P.C., Sievert, S.J., Shaver, R.D., Welch, D.A. \& Combs, D.K., 1993. In situ dry matter, protein, and fiber degradation of perennial forages. J. Dairy Sci. 76, 2632-2643.

Huhtanen, P., Vanhatalo, A. \& Varvikko, T., 1998. Enzyme activities of rumen particles and feed samples incubated in situ with differing types of cloth. Br. J. Nutr. 79, 161-168.

Huhtanen, P., Khalili, H., Nousiainen, J.I., Rinne, M., Jaakkola, S., Heikkilä, T. \& Nousiainen, J., 2002. Prediction of the relative intake potential of grass silage by dairy cows. Livest. Prod. Sci. 73, 111-130.

Huhtanen, P., Nousiainen, J. \& Rinne, M., 2006. Recent developments in forage evaluation with special reference to practical applications. Agric. Food Sci. 15, 293-323.

Jančík, F., Homolka, P., Čermák, B. \& Lád, F., 2008. Determination of indigestible neutral detergent fibre contents of grasses and its prediction from chemical composition. Czech J. Anim. Sci. 53, 128-135.

Jančík, F., Koukolová, V., Kubelková, P. \& Čermák, B., 2009. Effects of grass species on ruminal degradability of silages and prediction of dry matter effective degradability. Czech J. Anim. Sci. 54, 315-323.

Jančík, F., Koukolová, V. \& Homolka, P., 2010. Ruminal degradability of dry matter and neutral detergent fibre of grasses. Czech J. Anim. Sci. 55, 359-371.

Jensen, K.B., Waldron, B.L., Asay, K.H., Johnson, D.A. \& Monaco, T.A., 2003. Forage nutritional characteristics of orchardgrass and perennial ryegrass at five irrigation levels. Agron. J. 95, 668-675.

Jung, H.G., Mertens, D.R. \& Payne, A.J., 1997. Correlation of acid detergent lignin and klason lignin with digestibility of forage dry matter and neutral detergent fiber. J. Dairy Sci. 80, 1622-1628.

Khazaal, K., Dentinho, M.T., Ribeiro, J.M. \& Ørskov, E.R., 1995. Prediction of apparent digestibility and voluntary intake of hays fed to sheep: comparison between using fibre components, in vitro digestibility or characteristics of gas production or nylon bag degradation. Anim. Sci. 61, 527-538.

Koukolová, V., Weisbjerg, M.R., Hvelplund, T., Lund, P. \& Čermák, B., 2004. Prediction of NDF degradation characteristics of grass and grass/clover forages based on laboratory methods. J. Anim. Feed Sci. 13, 691-708.

Kvasnička, F., 2000. Application of isotachophoresis in food analysis. Electrophoresis 21, 2780-2787. 
Lund, P., Weisbjerg, M.R., Ahvenjärvi, S., Huhtanen, P., Uden, P., Olafsson, B. \& Volden, H., 2004. Nordic ringtest on INDF content and NDF degradation characteristics in three feeds. J. Anim. Feed Sci. 13, 139-142.

Lund, P., Weisbjerg, M.R., Hvelplund, T. \& Knudsen, K.E.B., 2007. Determination of digestibility of different forages in dairy cows using indigestible NDF as marker. Acta Agric. Scand. 57, 16-29.

Nagadi, S., Herrero, M. \& Jessop, N.S., 2000. The effect of fermentable nitrogen availability on in vitro gas production and degradability of NDF. Anim. Feed Sci. Technol. 87, 241-251.

Nousiainen, J., Rinne, M., Helämäki, M. \& Huhtanen, P., 2003a. Prediction of the digestibility of the primary growth of grass silages harvested at different stages of maturity from chemical composition and pepsin-cellulase solubility. Anim. Feed Sci. Technol. 103, 97-111.

Nousiainen, J., Rinne, M., Helämäki, M. \& Huhtanen, P., 2003b. Prediction of the digestibility of the primary growth and regrowth grass silages from chemical composition, pepsin-cellulase solubility and indigestible cell wall content. Anim. Feed Sci. Technol. 110, 61-74.

Nousiainen, J., Ahvenjärvi, S., Rinne, M., Hellämäki, M. \& Huhtanen, P., 2004. Prediction of indigestible cell wall fraction of grass silage by near infrared reflectance spectroscopy. Anim. Feed Sci. Technol. 115, 295-311.

Oba, M. \& Allen, M.S., 1999. Evaluation of the importance of the digestibility of neutral detergent fiber from forage: Effects on dry matter intake and milk yield of dairy cows. J. Dairy Sci. 82, 589-596.

Ørskov, E.R. \& McDonald, I., 1979. The estimation of protein degradability in the rumen from incubation measurements weighed according to rate of passage. J. Agric. Sci. 92, 499-503.

Petit, H.V. \& Tremblay, G.F., 1992. In situ degradability of fresh grass and grass conserved under different harvesting methods. J. Dairy Sci. 75, 774-781.

Pozdíšek, J., Loučka, R. \& Machačová, E., 2003. Digestibility and nutrition value of grass silages. Czech J. Anim. Sci. 48, 359-364.

Regulation No. 497/2004, 2004. Requirements of samples taking, methods for estimation of the feeds, supplements and premixes and way of samples storage. Collection of Law 2004. Czech Republic, part 172. (in Czech).

Rinne, M., Huhtanen, P. \& Jaakkola, S., 1997. Grass maturity effects on cattle fed silage-based diets. 2. Cell wall digestibility, digestion and passage kinetics. Anim. Feed Sci. Technol. 67, 19-35.

Rinne, M., Huhtanen, P. \& Jaakkola, S., 2002. Digestive processes of dairy cows fed silages harvested at four stages of grass maturity. J. Anim. Sci. 80, 1986-1998.

SAS, 2002-2003. SAS System for Windows, Release 9.1 (TS1M3), SAS Inst., Inc., Cary, N.C., USA.

Scheffé, H., 1953. A method for judging all contrasts in the analysis of variance. Biometrika 40, 87-104.

Skládanka, J., Dohnal, V. \& Ježková, A., 2008. Fibre and ergosterol contents in forage of Arrhenatherum elatius, Dactylis glomerata and Festulolium at the end of the growing season. Czech J. Anim. Sci. 53, 320-329.

Spanghero, M., Gruber, L. \& Zanfi, C., 2007. Precision and accuracy of the NDF rumen degradability of hays measured by the Daisy fermenter. Ital. J. Anim. Sci. 6, 363-365.

Taweel, H.Z., Tas, B.M., Smit, H.J., Elgersma, A., Dijkstra, J. \& Tamminga, S., 2005. Improving the quality of perennial ryegrass (Lolium perenne L.) for dairy cows by selecting for fast clearing and/or degradable neutral detergent fiber. Livest. Prod. Sci. 96, 239-248.

Traxler, M.J., Fox, D.G., Van Soest, P.J., Pell, A.N., Lascano, C.E., Lanna, D.P.D., Moore, J.E., Lana, R.P., Velez, M. \& Flores, A., 1998. Predicting forage indigestible NDF from lignin concentration. J. Anim. Sci. 76, 1469-1480.

Van Soest, P.J., 1994. Nutritional Ecology of the Ruminant. Cornell University. ISBN 0-8014-2772-X, 476 p.

Van Soest, P.J., Robertson, J.B. \& Lewis, B.A., 1991. Methods for dietary fiber, neutral detergent fiber, and nonstarch polysaccharides in relation to animal nutrition. J. Dairy Sci. 74, 3583-3597.

Wilman, D., Field, M., Lister, S.J. \& Givens, D.I., 2000. The use of near infrared spectroscopy to investigate the composition of silages and the rate and extent of cell-wall degradation. Anim. Feed Sci. Technol. 88, 139-151.

Yahaya, M.S., Kimura, A., Harai, J., Nguyen, H.V., Kawai, M., Takahashi, J. \& Matsuoka, S., 2001. Effect of length of ensiling on silo degradation and digestibility of structural carbohydrates of lucerne and orchardgrass. Anim. Feed Sci. Technol. 92, 141-148. 
Yan, T. \& Agnew, R.E., 2004. Prediction of nutritive values in grass silages: I. Nutrient digestibility and energy concentrations using nutrient compositions and fermentation characteristics. J. Anim. Sci. 82, 1367-1379.

Zadoks, J.C., Chang, T.T. \& Konzak, C.F., 1974. A decimal code for the growth stages of cereals. Weed Res. 14, 415-421.

Zhang, Y.Q., Gao, W. \& Meng, Q., 2007. Fermentation of plant cell walls by ruminal bacteria, protozoa and fungi and their interaction with fibre particle size. Arch. Anim. Nutr. 61, 114-125. 